\title{
Distinct disorders affecting the brain share common genetic origins
}

\author{
R Frank Kooy
}

Address: Department of Medical Genetics, University of Antwerp, Universiteitsplein 1, 2610 Antwerp, Belgium

Email: frank.kooy@ua.ac.be

FI000 Biology Reports 2010, 2:1 I (doi:10.34I0/B2-II)

The electronic version of this article is the complete one and can be found at: http://fl000.com/reports/biology/content/2/I I

\begin{abstract}
Over the last few years, large cohorts of patients with distinct brain disorders of neuropsychiatric and neurological origin have been analyzed for copy number variation. Surprisingly, the same genetic abnormalities were found in cohorts of patients affected with mental retardation, autism, or schizophrenia.
\end{abstract}

\section{Introduction and context}

Copy number variation in brain disease

According to recent estimates, 5-12\% of our genome is in a non-diploid state [1-3]. Copy number variation (CNV) discovery was enabled by the development of arraybased techniques that detect chromosomal abnormalities at a resolution that may exceed that of traditional karyotyping under a light microscope by orders of magnitude. Initially, bacterial artificial chromosome arrays were used with a resolution in the megabase range but these were gradually replaced by oligonucleotide arrays with a resolution in the 10- to 100-kilobase range, thus enabling the detection of detailed CNV maps of the human genome. Broadly speaking, CNVs fall into two categories: the common ones that occur in a significant proportion of the general population and the rare ones that have been detected at a much lower frequency. The common CNVs are generally assumed to play an important role in the natural variation between individuals, including disease susceptibility, whereas the rare ones may cause disease.

It is well established that CNVs are responsible for at least $10 \%$ of all cases of mental retardation [4], predominantly defined by an intelligence quotient of two standard deviations below the mean. Many of the rare $\mathrm{CNVs}$ identified are unique and have been reported only once. Whether these are pathogenic depends on a number of factors, including de novo occurrence, size of the deletion, and gene content. In contrast, recurrent CNVs are found in multiple unrelated patients, usually with common clinical manifestations [5]. Recurrent CNVs are mostly flanked by low copy repeats (LCRs), referred to as segmental duplications (Figure 1).

Over the past two years, cohorts of patients with disorders distinct from mental retardation were analyzed for CNV. Surprisingly, CNVs at specific chromosomal regions that are involved in mental retardation, including 1q21.1, 15q11-13, 16p11.2, 17p12, and 22q11.2, also appeared to be associated with autism (qualitative impairments in social interaction and communication) and schizophrenia (a psychotic disorder involving impairments in the perception of reality) (Figure 2). Moreover, the chromosomal regions encompassing the neurexin 1 (NRXN1) and the contactin-associated protein-like 2 (CNTNAP2) genes are also implicated in the three named disorders.

\section{Major recent advances \\ Copy number variation discovery in autism and schizophrenia}

Deletions of the chromosomal region 1q21.1, between two breakpoints (bps) defined as 3 and 4, were initially described with a wide range of pediatric phenotypes, including mild to moderate mental delay and dysmorphic 


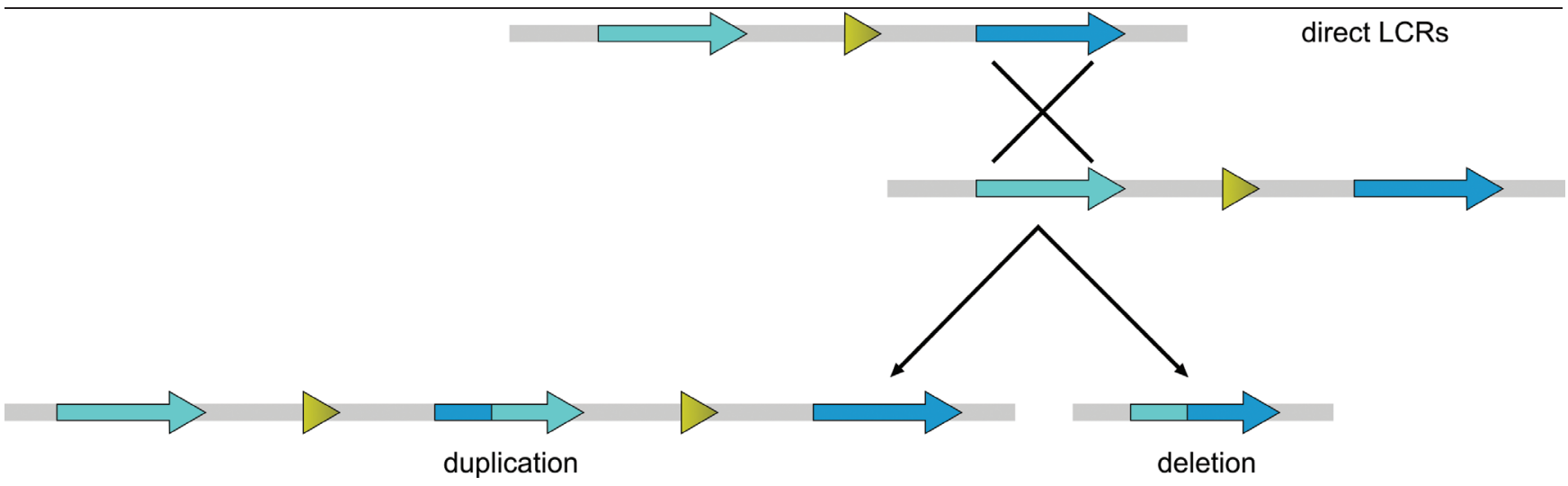

Schematic representation of the non-allelic homologous recombination process, generating deletions as well as their reciprocal duplications by unequal alignment of homologous chromosomes. LCR, low copy repeat.

Figure 2. Schematic overview of genetic overlaps between mental retardation, autism spectrum disorders, and schizophrenia

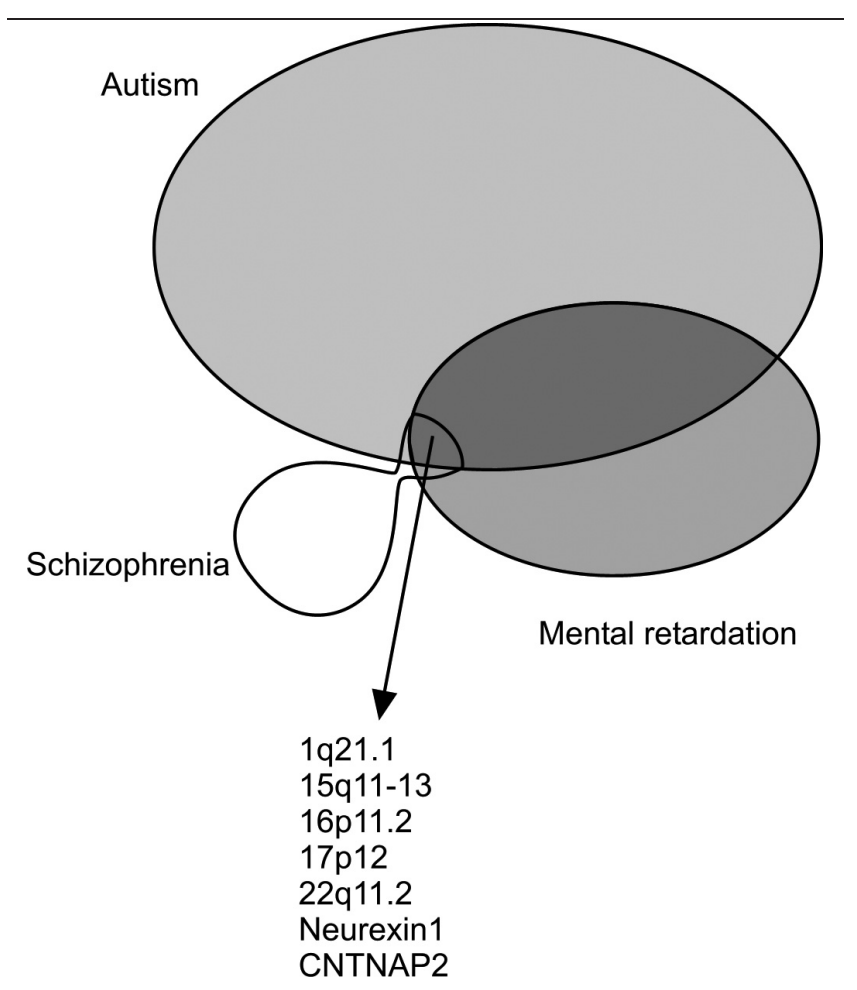

Copy number variations that cause mental retardation disorders overlap, to some extent, with those that cause autistic spectrum disorders and even with a few that cause schizophrenia. CNTNAP2, contactin-associated protein-like 2.

features, microcephaly, cardiac abnormalities, and cataract [6]. The reciprocal microduplication was found predominantly in patients who presented with autism or autistic features [6,7]. At the same time, 1q21.1 bp3-bp4 microdeletions were identified in $0.25 \%$ of patients with schizophrenia but in only $0.02 \%$ of controls [8-11].

The chromosomal 15q11-13 region has a complex molecular architecture containing five LCR sequences or breakpoints, and in addition this chromosomal region is subject to genomic imprinting. Paternal deletions of the region between bp2 and bp3 result in Prader-Willi syndrome whereas maternal deletions of the same region result in Angelman syndrome [12]. Patients with an extended bp1-bp3 deletion present with a more severe form of the disorder and more commonly display autistic features. Maternal duplications of the bp2-bp3 region cause a clinically variable neurodevelopmental disorder frequently associated with autism [13]. In fact, this duplication, found in 1-3\% of patients, is the leading known cause of this disorder. Deletions and occasionally duplications of the 15q13.3 bp4-bp5 region were found in patients with a highly variable degree of mental handicap, frequently including autistic features [14-16]. The same bp4-bp5 deletion was also one of the more frequently observed CNVs associated with schizophrenia [9]. The intermediate bp3-bp4 region seems of little clinical significance.

A 16p11.2 deletion was found initially in monozygotic twins with mild mental retardation and multiple congenital anomalies [17]. Subsequently, a strong association between the same microdeletion as well as the reciprocal microduplication and autism was reported [18-21]. The microdeletion is also found occasionally in controls, but with a 100-fold lower frequency. In addition, the microdeletion/duplication is a risk factor for schizophrenia $[8,10]$. 
But the abovementioned CNVs are not the only abnormalities associated with mental retardation, autism, and schizophrenia. A duplication of chromosome 17 p12 is generally associated with Charcot-Marie-Tooth disease type 1A (CMT1A) but is also occasionally found in mentally handicapped or autistic populations $[7,22]$. A deletion of the same chromosomal region increases the risk for schizophrenia by a factor of 10 [23]. One of the most frequent microdeletion syndromes, the 22q11.2 deletion, is associated with developmental delay in nearly $50 \%$ of patients. However, the same deletion is also found in autistic patients as well as in schizophrenic patients $[8,11,24]$. The phenotype of the reciprocal duplication is highly variable [25]. In addition, rearrangements involving the NRXN1 gene on chromosome $2 \mathrm{p} 16$ and the CNTNAP2 gene on chromosome $7 \mathrm{q} 35$ have been found in patients with mental retardation, autism, or schizophrenia $[7,8,10,26-31]$. Both genes are members of the larger neurexin superfamily involved in cell-cell interactions in the nervous system [32]. In contrast to the CNVs mentioned above, the deletions in these cases were highly variable in size.

\section{Future directions}

\section{Unexplained clinical heterogeneity}

Thus, several CNVs appear to cause a series of clinically heterogeneous brain disorders, including mental retardation, autism, and schizophrenia. Penetrance of these CNVs may vary and in some cases the abnormalities are inherited from seemingly unaffected carriers. Such inherited CNVs are better seen as risk factors than as a causative factor per se. For instance, penetrance of the 16p11.2 duplication in schizophrenia is estimated to be $30-50 \%$. In other words, carriers of this microduplication have an 8- to 24-fold increased risk of becoming affected [33], in range with that of other genomic aberrations taking away one copy of 1q21.1, 15q13 bp4-bp5, or NRXN1 [8,9,34]. While this overview focuses on mental retardation, autism, and schizophrenia, it has to be mentioned that many of the CNVs discussed above have also been associated with a broad range of additional phenotypes, most notably attention deficit hyperactivity disorder, epilepsy, and different psychiatric disorders, including bipolar and major depressive disorder. Interestingly, both the 16p11.2 microdeletion and the 1q21.1 microduplication are associated with a combination of autism and relative macrocephaly. An increased head circumference in infancy has been reported in patients with autism [35], suggesting a possible relationship between neurodevelopmental disorders and brain volume.

Interpretation of the clinical heterogeneity requires a greater understanding of how the CNVs lead to disease. For the most part, the disease resulting from a CNV is presumably due to an underexpression or overexpression of the genes in the deleted or duplicated region, respectively. In addition, it is possible that the deletion unmasks a recessive mutation on the other allele. However, imprinting, gene interruption, gene fusion, position, and transvection effects may also play a role in determining clinical heterogeneity and disease penetrance. In addition, it is possible that environmental variation of any kind influences the phenotype, but additional genetic factors could also play a role. The human genome is highly variant in both $\mathrm{CNV}$ content and single-nucleotide polymorphisms. Otherwise neutral genetic differences between individuals, in combination with the abovementioned CNVs, might determine whether the patient presents with mental retardation, autism, or schizophrenia. The only known example of such modifying genetic alterations at present is a recurrent $16 \mathrm{p} 12.1$ microdeletion that modifies neurobehavioral phenotypes [36]. The presence of this microdeletion in addition to a second pathogenic CNV manifests clinically as mental retardation. Perhaps the analysis of new cohorts with an even larger number of samples might help us to identify additional modifiers unknown as of yet. Alternatively, studying the CNV in animal models with a much more controllable genetic background seems attractive [37]. Thus, although some of the genetic origins of neurodevelopmental disorders are now beginning to be understood, many discoveries need to be made before we will begin to understand the common pathways leading to each of these disorders.

\section{Abbreviations}

bp, breakpoint; CNTNAP2, contactin-associated proteinlike 2; CNV, copy number variation; LCR, low copy repeat; NRXN1, neurexin 1.

\section{Competing interests}

The author declares that he has no competing interests.

\section{Acknowledgments}

The author thanks Denise Kerstens for help with the figures.

\section{References}

I. Zhang F, Gu W, Hurles ME, Lupski JR: Copy number variation in human health, disease, and evolution. Annu Rev Genomics Hum Genet 2009, 10:451-81.

2. Sebat J, Lakshmi B, Troge J, Alexander J, Young J, Lundin P, Månér S, Massa H, Walker M, Chi M, Navin N, Lucito R, Healy J, Hicks J, Ye K, Reiner A, Gilliam TC, Trask B, Patterson N, Zetterberg A, Wigler M: Large-scale copy number polymorphism in the human genome. Science 2004, 305:525-8.

FI000 Factor 8.5 Exceptional

Evaluated by Andrew Wilkie 16 Aug 2004, Michael O'Donovan 22 Sep 2004, Stephen Scherer 23 Sep 2004, Andrey Rzhetsky 24 Sep 2004, Niklas Dahl 04 Oct 2004, Andrew Belmont I 4 Oct 2004 
3. lafrate AJ, Feuk L, Rivera MN, Listewnik ML, Donahoe PK, Qi $Y$, Scherer SW, Lee C: Detection of large-scale variation in the human genome. Nat Genet 2004, 36:949-5I.

FI000 Factor 6.7 Must Read

Evaluated by Vivian Cheung 27 Aug 2004, Molly Przeworski 21 Sep 2004, Niklas Dahl 04 Oct 2004, Magnus Nordborg 14 Oct 2004

4. Koolen DA, Pfundt R, de Leeuw N, Hehir-Kwa JY, Nillesen WM, Neefs I, Scheltinga I, Sistermans E, Smeets D, Brunner HG, van Kessel AG, Veltman JA, de Vries BBA: Genomic microarrays in mental retardation: a practical workflow for diagnostic applications. Hum Mutat 2009, 30:283-92.

5. Koolen DA, Vissers LELM, Pfundt R, de Leeuw N, Knight SJL, Regan R, Kooy RF, Reyniers E, Romano C, Fichera M, Schinzel A, Baumer A, Anderlid B-M, Schoumans J, Knoers NV, Geurts van Kessel A, Sistermans EA, Veltman J, Brunner HG, de Vries BBA: A new chromosome $17 \mathrm{q} 21.31$ microdeletion syndrome associated with a common inversion polymorphism. Nat Genet 2006, 38:999-100I.

FI000 Factor 6.0 Must Read

Evaluated by Sue Malcolm 25 Sep 2006

6. Mefford HC, Sharp AJ, Baker C, Itsara A, Jiang Z, Buysse K, Huang S, Maloney VK, Crolla JA, Baralle D, Collins A, Mercer C, Norga K, de Ravel T, Devriendt K, Bongers EM, de Leeuw N, Reardon W, Gimelli S, Bena F, Hennekam RC, Male A, Gaunt L, Clayton-Smith J, Simonic I, Park SM, Mehta SG, Nik-Zainal S, Woods CG, Firth HV, et al.: Recurrent rearrangements of chromosome Iq2I.I and variable pediatric phenotypes. $N$ Engl J Med 2008, 359:1685-99.

7. Szatmari $P$, Paterson $A D, Z$ waigenbaum L, Roberts $W$, Brian J, Liu $X Q$, Vincent JB, Skaug JL, Thompson AP, Senman L, Feuk L, Qian C, Bryson SE, Jones MB, Marshall CR, Scherer SW, Vieland V], Bartlett C, Mangin LV, Goedken R, Segre A, Pericak-Vance MA, Cuccaro ML, Gilbert JR, Wright HH, Abramson RK, Betancur C, Bourgeron T, Gillberg C, Leboyer M, et al.: Mapping autism risk loci using genetic linkage and chromosomal rearrangements. Nat Genet 2007, 39:319-28.

FI000 Factor 3.0 Recommended

Evaluated by Jens Rettig 04 Apr 2007

8. International Schizophrenia Consortium: Rare chromosomal deletions and duplications increase risk of schizophrenia. Nature 2008, 455:237-41.

9. Stefansson H, Rujescu D, Cichon S, Pietilainen OP, Ingason A, Steinberg S, Fossdal R, Sigurdsson E, Sigmundsson T, Buizer-Voskamp JE, Hansen T, Jakobsen KD, Muglia P, Francks C, Matthews PM, Gylfason A, Halldorsson BV, Gudbjartsson D, Thorgeirsson TE, Sigurdsson A, Jonasdottir A, Jonasdottir A, Bjornsson A, Mattiasdottir S, Blondal T, Haraldsson M, Magnusdottir BB, Giegling I, Moller HJ, Hartmann A, et al.: Large recurrent microdeletions associated with schizophrenia. Nature 2008, 455:232-6.

FI000 Factor 6.0 Must Read

Evaluated by Karoly Mirnics 08 Aug 2008

10. Walsh T, McClellan JM, McCarthy SE, Addington AM, Pierce SB, Cooper GM, Nord AS, Kusenda M, Malhotra D, Bhandari A, Stray SM, Rippey CF, Roccanova P, Makarov V, Lakshmi B, Findling RL, Sikich L, Stromberg T, Merriman B, Gogtay N, Butler P, Eckstrand K, Noory L, Gochman P, Long R, Chen Z, Davis S, Baker C, Eichler EE, Meltzer PS, et al:: Rare structural variants disrupt multiple genes in neurodevelopmental pathways in schizophrenia. Science 2008 , 320:539-43.

FI000 Factor 8.4 Exceptional

Evaluated by Jonathan Flint 08 Apr 2008, Gordon Fishell 09 Apr 2008, Michael Owen 09 Apr 2008, Guoping Feng 22 Apr 2008, Sue Malcolm 20 May 2008

II. Xu B, Roos JL, Levy S, van Rensburg EJ, Gogos JA, Karayiorgou M: Strong association of de novo copy number mutations with sporadic schizophrenia. Nat Genet 2008, 40:880-5.

FI000 Factor 3.0 Recommended

Evaluated by Peter Scambler I4 Jul 2008
12. Sahoo T, Bacino CA, German JR, Shaw CA, Bird LM, Kimonis V, Anselm I, Waisbren S, Beaudet AL, Peters SU: Identification of novel deletions of $15 \mathrm{q}|\mathrm{I}| \mathrm{I} 3$ in Angelman syndrome by arrayCGH: molecular characterization and genotype-phenotype correlations. Eur J Hum Genet 2007, 15:943-9.

13. Cook EH Jr, Lindgren V, Leventhal BL, Courchesne R, Lincoln A, Shulman C, Lord C, Courchesne E: Autism or atypical autism in maternally but not paternally derived proximal I5q duplication. Am J Hum Genet 1997, 60:928-34.

14. Sharp AJ, Mefford HC, Li K, Baker C, Skinner C, Stevenson RE, Schroer RJ, Novara F, De Gregori M, Ciccone R, Broomer A, Casuga I, Wang Y, Xiao C, Barbacioru C, Gimelli G, Dalla Bernardina B, Torniero C, Giorda R, Regan R, Murday V, Mansour S, Fichera M, Castiglia L, Failla P, Ventura M, Jiang Z, Cooper GM, Knight SJL, Romano C, et al.: A recurrent I5q13.3 microdeletion syndrome associated with mental retardation and seizures. Nat Genet 2008, 40:322-8.

15. van Bon BW, Mefford HC, Menten B, Koolen DA, Sharp AJ, Nillesen WM, Innis JW, de Ravel TJ, Mercer CL, Fichera M, Stewart H, Connell LE, Ounap K, Lachlan K, Castle B, Van der Aa N, van Ravenswaaij C, Nobrega MA, Serra-Juhé C, Simonic I, de Leeuw N, Pfundt R, Bongers EM, Baker C, Finnemore P, Huang S, Maloney VK, Crolla JA, van Kalmthout M, Elia M, et al:: Further delineation of the $15 q / 3$ microdeletion and duplication syndromes: a clinical spectrum varying from non-pathogenic to a severe outcome. J Med Genet 2009, 46:5 I I-23.

16. Pagnamenta AT, Wing K, Akha ES, Knight SJ, Bolte S, Schmotzer G, Duketis E, Poustka F, Klauck SM, Poustka A, Ragoussis J, Bailey AJ, Monaco AP: A I5qI3.3 microdeletion segregating with autism. Eur J Hum Genet 2009, 17:687-92.

17. Ghebranious N, Giampietro PF, Wesbrook FP, Rezkalla SH: A novel microdeletion at I6p|l.2 harbors candidate genes for aortic valve development, seizure disorder, and mild mental retardation. Am J Med Genet 2007, I 43A:I462-7I.

18. Sebat J, Lakshmi B, Malhotra D, Troge J, Lese-Martin C, Walsh T, Yamrom B, Yoon S, Krasnitz A, Kendall J, Leotta A, Pai D, Zhang R, Lee YH, Hicks J, Spence SJ, Lee AT, Puura K, Lehtimaki T, Ledbetter D, Gregersen PK, Bregman J, Sutcliffe JS, Jobanputra V, Chung W, Warburton D, King MC, Skuse D, Geschwind DH, Gilliam TC, et al.: Strong association of de novo copy number mutations with autism. Science 2007, 3 I6:445-9.

FI000 Factor 6.9 Must Read

Evaluated by Stephen Scherer 13 Apr 2007, James Fry 27 Apr 2007, Andrey Rzhetsky 02 May 2007, John Rubenstein 08 Jun 2007, Guoping Feng 25 Jul 2007

19. Weiss LA, Shen Y, Korn JM, Arking DE, Miller DT, Fossdal R, Saemundsen E, Stefansson H, Ferreira MAR, Green T, Platt OS, Ruderfer DM, Walsh CA, Altshuler D, Chakravarti A, Tanzi RE, Stefansson K, Santangelo SL, Gusella JF, Sklar P, Wu B-L, Daly MJ: Association between microdeletion and microduplication at I6p I I.2 and autism. N Engl J Med 2008, 358:667-75.

FI000 Factor 3.2 Recommended

Evaluated by Stephen Scherer 24 Jan 2008, Sue Malcolm 07 Feb 2008

20. Kumar RA, KaraMohamed S, Sudi J, Conrad DF, Brune C, Badner JA, Gilliam TC, Nowak NJ, Cook EH Jr, Dobyns WB, Christian SL: Recurrent $16 \mathrm{p}$ II.2 microdeletions in autism. Hum Mol Genet 2008, 17:628-38.

21. Christian SL, Brune CW, Sudi J, Kumar RA, Liu S, Karamohamed S, Badner JA, Matsui S, Conroy J, McQuaid D, Gergel J, Hatchwell E, Gilliam TC, Gershon ES, Nowak NJ, Dobyns WB, Cook EH Jr: Novel submicroscopic chromosomal abnormalities detected in autism spectrum disorder. Biol Psychiatry 2008, 63:IIII-7.

22. de Vries BBA, Pfundt R, Leisink M, Koolen DA, Vissers LELM, Janssen IM, van Reijmersdal S, Nillesen WM, Huys EHLPG, de Leeuw N, Smeets D, Sistermans EA, Feuth T, van RavenswaaijArts CMA, Geurts van Kessel A, Schoenmakers EFPM, Brunner HG, 
Veltman JA: Diagnostic genome profiling in mental retardation. Am J Hum Genet 2005, 77:606-16.

FI000 Factor 3.0 Recommended

Evaluated by Stephen Scherer 19 Sep 2005

23. Kirov G, Grozeva D, Norton N, Ivanov D, Mantripragada KK, Holmans P, Craddock N, Owen MJ, O'Donovan MC: Support for the involvement of large copy number variants in the pathogenesis of schizophrenia. Hum Mol Genet 2009, 18:1497503.

24. Marshall CR, Noor A, Vincent JB, Lionel AC, Feuk L, Skaug J, Shago M, Moessner R, Pinto D, Ren Y, Thiruvahindrapduram B, Fiebig A, Schreiber S, Friedman J, Ketelaars CEJ, Vos YJ, Ficicioglu C, Kirkpatrick S, Nicolson R, Sloman L, Summers A, Gibbons CA, Teebi A, Chitayat D, Weksberg R, Thompson A, Vardy C, Crosbie V, Luscombe S, Baatjes R, et al.: Structural variation of chromosomes in autism spectrum disorder. Am J Hum Genet 2008, 82:477-88.

25. Emanuel BS: Molecular mechanisms and diagnosis of chromosome 22q I I.2 rearrangements. Dev Disabil Res Rev 2008, I4: I -8.

26. Chubykin AA, Liu X, Comoletti D, Tsigelny I, Taylor P, Sudhof TC: Dissection of synapse induction by neuroligins: effect of a neuroligin mutation associated with autism. J Biol Chem 2005, 280:22365-74.

27. Feng J, Schroer R, Yan J, Song W, Yang C, Bockholt A, Cook EH Jr, Skinner C, Schwartz CE, Sommer SS: High frequency of neurexin Ibeta signal peptide structural variants in patients with autism. Neurosci Lett 2006, 409:10-3.

28. Zahir FR, Baross A, Delaney AD, Eydoux P, Fernandes ND, Pugh T, Marra MA, Friedman JM: A patient with vertebral, cognitive and behavioural abnormalities and a de novo deletion of NRXN I alpha. J Med Genet 2008, 45:239-43.

29. Friedman JM, Baross A, Delaney AD, Ally A, Arbour L, Asano J, Bailey DK, Barber S, Birch P, Brown-John M, Cao M, Chan S, Charest DL, Farnoud N, Fernandes N, Flibotte S, Go A, Gibson WT, Holt RA, Jones SJM, Kennedy GC, Krzywinski M, Langlois S, Li HI, McGillivray BC, Nayar T, Pugh TJ, Rajcan-Separovic E, Schein JE, Schnerch $A$, et al:: Oligonucleotide microarray analysis of genomic imbalance in children with mental retardation. Am J Hum Genet 2006, 79:500-I3.

30. Strauss KA, Puffenberger EG, Huentelman MJ, Gottlieb S, Dobrin SE, Parod JM, Stephan DA, Morton DH: Recessive symptomatic focal epilepsy and mutant contactin-associated protein-like 2. N Engl J Med 2006, 354: 1370-7.

FI000 Factor 3.0 Recommended

Evaluated by Angela Vincent 16 May 2006
3I. Friedman Jl, Vrijenhoek T, Markx S, Janssen IM, van der Vliet WA, Faas BH, Knoers NV, Cahn W, Kahn RS, Edelmann L, Davis KL, Silverman JM, Brunner HG, van Kessel AG, Wijmenga C, Ophoff RA, Veltman JA: CNTNAP2 gene dosage variation is associated with schizophrenia and epilepsy. Mol Psychiatry 2008, 13:261-6.

FI000 Factor 3.0 Recommended

Evaluated by Michael Owen 27 Nov 2007

32. Sudhof TC: Neuroligins and neurexins link synaptic function to cognitive disease. Nature 2008, 455:903-II.

33. McCarthy SE, Makarov V, Kirov G, Addington AM, McClellan J, Yoon S, Perkins DO, Dickel DE, Kusenda M, Krastoshevsky O, Krause V, Kumar RA, Grozeva D, Malhotra D, Walsh T, Zackai EH, Kaplan P, Ganesh J, Krantz ID, Spinner NB, Roccanova P, Bhandari A, Pavon K, Lakshmi B, Leotta A, Kendall J, Lee YH, Vacic V, Gary S, lakoucheva LM, et al:: Microduplications of $16 \mathrm{p} \mid 1.2$ are associated with schizophrenia. Nat Genet 2009, 41:1223-7.

FI000 Factor 6.0 Must Read

Evaluated by Francine Benes 13 Nov 2009

34. Rujescu D, Ingason A, Cichon S, Pietilainen OP, Barnes MR, Toulopoulou T, Picchioni M, Vassos E, Ettinger U, Bramon E, Murray R, Ruggeri M, Tosato S, Bonetto C, Steinberg S, Sigurdsson E, Sigmundsson T, Petursson H, Gylfason A, Olason PI, Hardarsson G, Jonsdottir GA, Gustafsson O, Fossdal R, Giegling I, Moller HI, Hartmann AM, Hoffmann P, Crombie C, Fraser G, et al: Disruption of the neurexin I gene is associated with schizophrenia. Hum Mol Genet 2009, I 8:988-96.

FI000 Factor 6.0 Must Read

Evaluated by Francine Benes 28 Sep 2009

35. Fukumoto A, Hashimoto $T$, Ito $H$, Nishimura M, Tsuda $Y$, Miyazaki M, Mori K, Arisawa K, Kagami S: Growth of head circumference in autistic infants during the first year of life. J Autism Dev Disord 2008, 38:4II-8.

36. Girirajan S: A recurrent $\mid 6 \mathrm{p} / 2.1$ microdeletion modifies neurobehavioral phenotypes. Paper presented at American Society of Human Genetics 59th Annual Meeting; 20-24 October 2009; Honolulu, HI, USA. Program 263.

37. Churchill GA, Airey DC, Allayee H, Angel JM, Attie AD, Beatty J, Beavis WD, Belknap JK, Bennett B, Berrettini W, Bleich A, Bogue M, Broman KW, Buck KJ, Buckler E, Burmeister M, Chesler EJ, Cheverud JM, Clapcote S, Cook MN, Cox RD, Crabbe JC, Crusio WE, Darvasi A, Deschepper CF, Doerge RW, Farber CR, Forejt J, Gaile D, Garlow SJ, et al.: The Collaborative Cross, a community resource for the genetic analysis of complex traits. Nat Genet 2004, 36: I I33-7. 